Intersections

Canadian Journal of Music

Revue canadienne de musique
Intersections

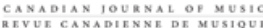

\title{
How to win at SSHRC
}

\section{Murray Dineen}

Volume 28, numéro 1, 2007

URI : https://id.erudit.org/iderudit/019289ar

DOI : https://doi.org/10.7202/019289ar

Aller au sommaire du numéro

\section{Éditeur(s)}

Canadian University Music Society / Société de musique des universités canadiennes

ISSN

1911-0146 (imprimé)

1918-512X (numérique)

Découvrir la revue

Citer ce document

Dineen, M. (2007). How to win at SSHRC. Intersections, 28(1), 3-10.

https://doi.org/10.7202/019289ar

Tous droits réservés (C) Canadian University Music Society / Société de musique des universités canadiennes, 2007
Ce document est protégé par la loi sur le droit d'auteur. L’utilisation des services d'Érudit (y compris la reproduction) est assujettie à sa politique d'utilisation que vous pouvez consulter en ligne.

https://apropos.erudit.org/fr/usagers/politique-dutilisation/
Cet article est diffusé et préservé par Érudit.

Érudit est un consortium interuniversitaire sans but lucratif composé de l’Université de Montréal, l'Université Laval et l'Université du Québec à Montréal. Il a pour mission la promotion et la valorisation de la recherche. https://www.erudit.org/fr/ 


\section{EDITORIAL: How TO WIN AT SSHRC}

The Social Sciences and Humanities Research Council of Canada (SSRHC) goes through an annual adjudication exercise every March, the purpose of which is to allocate a very generous (but never truly sufficient) amount of funding to Canadian academic researchers under the rubric of the Standard Research Grant programme (SRG). In the past, I've described this to my colleagues as a lottery: you fills out your form; you takes your chances. Having received several SRG's (and lost out on more than a few applications), I'm more than willing to dole out a little advice about how to write an SRG application-how to win at SSHRC, in other words.

Over the past two years, however, I have been invited by SSHRC to participate in the annual adjudication of SSHRC SRG grants for the Fine Arts. Sequestered in an airless basement room in an Ottawa hotel for some four days, 8:30 to 5, I've come to gain a new appreciation for the exercise. Prior to this, the SSHRC process seemed monolithic (like so much that gets done here in Ottawa); now it seems, well, monolithic, but at least I understand the process, and I see something of its benefit, although, as I shall set forth shortly, I believe this can be improved upon.

We are all winners at SSHRC, even if we, hapless souls, don't always have our applications picked for funding. SSHRC funding remains the lifeblood of humanities and social science research in Canada, be it in the form of the SRG's, or assistance to journals such as Intersections, or to the Canadian Federation of Humanities and Social Sciences (FedCan) which among other things puts together the annual Congress where CUMS/SMUC usually meets, or any number of other projects that SSHRC quietly, in fact a little too reticently, goes about putting together. But in order to truly "win" at SSRHC, to reap full benefit of their largesse, Canadian scholars like you and me could be better involved in its processes and deliberations, either as private citizens, or through CUMS/ SMUC, or through FedCan. In other words, you don't win at SSHRC just by getting a grant. We all win at SSHRC by participating wherever possible in its affairs and by working for it-for example, by accepting requests to serve on the adjudication panels, or speaking with SSHRC officers when something in the competition is unclear or unfair.

The purpose of this editorial is two fold: first, to describe something of the operations of the annual SRG exercise, the better to explain it to potential "winners" of SSHRC grants who are readers of Intersections, and secondly, to raise issues that merit our interest in SSHRC's programmes, the SRG in particular but not exclusively. This editorial begins, then, with a description of the SRC adjudication, and concludes by drawing attention to general aspects of SSHRC that might prove of interest to music scholars working in Canada. 


\section{The Adjudication}

In an attempt to make the SRG application process a little less monolithic, I shall address this section to the potential applicant. Your application to the SRG is adjudicated by a committee of about ten members, comprising normally an officer from SSHRC who oversees a number of tasks related to the adjudication (from inviting external readers of the applications in the fall of the year, to compiling and reporting the final results of the adjudication in the subsequent spring), a committee chair who conducts the adjudication meetings, and eight committee members who present a selection of files to the remainder of the committee and in doing so assign a score to each file. The scores assigned (often modified with the input of the other committee members) determine the ranking of your file-the order according to which the highest ranking files are selected for funding.

I participated these last two years as a member of Committee 3, assigned to the adjudication of the Fine Arts. The latter is a slight misnomer, since the actual creation of art under the rubric of the fine arts has fallen to another programme, Research Creation, sadly no longer funded by SSHRC but with good potential for revival. Instead Committee 3 examines files that take the fine arts as the subject matter of social sciences and humanities investigation. (From time to time, the boundary between research creation and social sciences and humanities investigation becomes moot, but in general a working distinction is drawn between projects that create art and those that address art from scientific and humanistic perspectives.) The mandate of Committee 3 sometimes overlaps with that of other committees, for example the committee assigned interdisciplinary projects. But in general there is a consistency to the kind of file seen by committee members-subject matter pertinent to the current research trajectories of the social sciences and humanities in Canadian universities and colleges. Within this consistency, however, are certain disciplinary tensions that distinguish between files and make some perhaps more suited to SSHRC's mandate (which I shall address below).

If you apply to the Standard Research Grant programme (having spent at best estimate something near a month preparing your application and delivering it to the appropriate research office of your university or college), your file makes its way to the appropriate SSHRC committee. On its way, however, it is shared with at least two (sometimes three or even four) assessors, the external readers, who follow a standard assessment format in reporting the merits of the application to SSHRC. (These assessment reports are delivered to you when SSHRC announces whether or not your project has received funding.) The assessors are chosen by the SSHRC officer, who draws upon experts of some standing in the appropriate field, and quite often foreign scholars (who may or may not understand either SSHRC's mandate or the present condition of scholarship in Canada, a point to be returned to below). Committee members take into account these assessments in adjudicating a file, but may decide to adopt only a portion of the assessment or to ignore it entirely (say, for example, in the rare instance where the assessor is abusive or derogatory), having first explained this decision to the other members of the committee. 
Early in the new year, SSHRC assembles the files to be read by a given committee, along with the external assessments that have been returned at that time, and commits these to a DVD, which it then sends to committee members. As more assessor reports are received, SSHRC adds these to the files and sends out revised DVD's. Usually by mid-February most assessor's reports are received (and committee members take the opportunity given by reading break to complete their reading of the DVD). Before this, however, a conference call among the members of the committee is made, its purpose being to "calibrate," to give new committee members an idea of how the evaluation is made, and to give some idea as well of the kind of ranking various committee members would make. Some committee members will rank all files high and then revise downwards as the deliberations proceed, and vice versa. The calibration gives the members a preview of how the committee is inclined to assign marks, which they take into account in making their own decisions.

Normally Committee 3 sees from about 100 to 120 files in total. Where conflict of interest is perceived, a reader will not address a file and will excuse themselves from the room during its deliberation by the committee. I cannot, for example, be present when a file from my university is discussed, and I regularly remove myself when a file from another university with which I have close and extended contact comes before me. Of the 100 to 120 files, about one quarter are assigned to each committee member. In other words, while each committee member is encouraged to read 120 files, they are assigned about 30 files to read in detail. Of these 30 files, the committee member reads half as the principal reader (Reader A), the expert on the file, and half as an auxiliary reader (Reader B), the back up reader on the file. Of the 30 files that any reader sees, about half will be files of "New Scholars"(scholars who have not been employed full time by a university or college for more than five years) and half will be "Regular Scholars" (those employed longer than five years).

During the adjudication meetings, Reader A-the principal or expertpresents the file in question to the committee. They begin by describing the content and scope of the project proposed, the nature of its budget, and the assessors' reports. Reader A concludes by assigning the application a two-part numeric score-first an assessment of the project, secondly an assessment of the applicant's curriculum vitae and professional career as it relates to the project. Reader B then adds brief comments on the file, in particular its budget, and supplies their own two-part score, which may or may not agree with the scores of Reader A. Where there is a large discrepancy between the two readers, the Chair will normally ask them to reconcile their differences, if only in part. The whole process of presenting the file to the committee takes from about 10 to 15 minutes normally, although the presentation might take less time, and certainly on occasion takes more time. Committees meet normally in later winter here in Ottawa's finest stuffy hotels, for three to four days (a portion of the fourth day being given over to discussion of SSHRC policies pertinent to the adjudication process).

Readers A and B normally supply working scores for the files assigned them to the SSHRC officer prior to the meeting. From these, a preliminary ranking 
is arrived at. The highest ranked files are usually assured of funding, and at the March meeting the committee may choose to review these quickly, in order to proceed to files in the middle of the ranking, whose merits are somewhat less clear cut. In other words, if both readers A and B rank your file as particularly worthy, its funding is almost assured, and so it is set aside, making room for more contentious files-middle and low ranked files. The middle ranked files are examined in considerable detail, in particular their budgets. Although the committee tries never to cut a budget item essential to the project, it will remove items that are not well justified in the application or that exceed the norms of research costs in the discipline. In cutting from one file, they free up resources that can be applied to files that otherwise might go unfunded.

SSHRC assigns a set amount of funding to each committee. As the meetings proceed, the committee works downward from those highest ranked files, which are assured of funding, to the middle rank files, and as it does so, a cut off point emerges, after which SSHRC funds are no longer available. The committee may still recommend files for funding - the mysterious "recommended but not funded" designation-after this point (and sometimes SSHRC manages to obtain more funding from the government at a date later than the March adjudications), but given its budget, a moment is arrived at after which in all likelihood files will not receive funding. The moment is most disconcerting for committee members, especially since so many of these middle-rank files have obvious merit. The committee changes its approach as it nears this cut off point: debates about the merits of a file can become extended, and budgets are scrutinized repeatedly, often with extreme care.

Since all files must be ranked, however, the adjudication process continues with the low-ranked files. Here, the committee changes its approach again, to concentrate its energies on making recommendations for improvements and thus encouraging the applicant to try again in the next year's competition. Once the whole complement of files has been ranked, the committee may choose to return to the highest ranked files, and consider them again in detail. Ultimately the final assessment is reached, and the SSHRC officer and committee chair conclude the adjudications. The last day of the process is given over in part or in whole to recommendations about the funding process and by extension the programme itself.

Before turning to problems I discern in the SRG programme, I will venture a few suggestions about how to succeed at getting a grant, based on my limited experience of two years.

1. Above all represent yourself. On the one hand show a certain modesty. You should be capable of completing the project proposed; unless you have a major track record with grants, don't propose a massive project that would seem to push your abilities. On the other hand, don't be too modest. SSHRC is concerned with innovation, with getting bang from its buck (more about this below). Your project should show at least a modicum of adventure, and a certain enthusiasm on your part.

2. Make your project discrete. Don't try to hide a decade's worth of work within the normal three-year SRG time frame. If you return to SSHRC every three years by morphing one project into another, you will tempt 
the committee's patience. SSHRC funds research projects, not scholarly careers. Distinguish clearly your proposed research from present and past.

3. Situate yourself in your scholarly environment. Don't reinvent the wheel, but place yourself and your project in the scholarly community. Unless you have a drastic rethinking of research paradigms in mind (and a really good scholarly record behind you), build your work on the shoulders of others. Put together a good, lengthy bibliography, and orient your proposal to it.

4. Don't pad your budget. Yes, chances are good that your budget will be cut back, but don't inflate it accordingly. Since the members of your adjudication committee are your colleagues and have seen several hundred applications by the moment they reach yours, they have a pretty good idea of what's realistic. If your budget appears unrealistic, it might be held against you.

5. Find some way to incorporate students, preferably graduate students, into your budget. Someone taught you how to research, so return the favour. Find some meaningful tasks - not just secretarial-for students, be it bibliographical, collecting data, or even analysis of data. And build in time to discuss your research with your students. But don't treat the SRG's as a means of funding a whole graduate programme. If you are intent on creating a large research team involving many students, you should be very precise about the duties involved and the time to be allotted.

6. The dissemination of your research results should be peer reviewed. Private or even institutional non-peer reviewed websites do not constitute a suitable outlet for SSHRC funded research. You may wish to place related, or spin-off research there, but SSHRC has to know that its funded research will meet the standards of peer evaluation in its respective fields. Since plenty of opportunities exist, either in Canada or abroad, you should clearly outline the potential peer-reviewed areas of dissemination.

7. Link your application to your institution. If you come from a small or an undergraduate university, state that clearly. Committees take into account the fact that small institutions might lack the kind of support afforded by the big universities. In particular, the big universities-and middle-sized ones like mine-often have offices that vet SRG applications, a fact that puts smaller institutions at a distinct disadvantage.

8. Above all, seek help with your application. Contact SSHRC for help (and they are usually very helpful, although frequently overworked); look around for a colleague in your institution who has a good SRG track record (ask your chair or dean); push your learned society-CUMS/SMUC, for example-to find someone to vet SSHRC applications from smaller institutions.

9. Set aside at least a month of hard work. The prose descriptions of the project, the budget and its justification, the bibliography, your c.v., and even the SSHRC website itself-all of these require time. And bear in mind your institutional deadlines, which can be dramatically earlier than those of SSHRC itself.

Its severity aside, the SSHRC application is usually worth attempting. It shows to your colleagues-your chair and dean in particular-that you are ser- 
ious about the role of research in your professional life. Although I know of one applicant who went a decade without success, and many for whom four and even five applications were required, we all win by the process, for we are all made better scholars through explaining ourselves to others.

\section{Problems with the Adjudication Process (and Some Proposed Remedies)}

As Canadian scholars-the winners in this whole exercise-we should be concerned about the SRG competition, and about the pressures, both fiscal and political, being exerted upon SSHRC.

1. First and foremost, there is the very scope of the process itself, which dates in conception from an era certainly well before the advent of the internet. Four days of adjudication at 15 minutes a file tries the judgment of anyone, and in that sense the process cannot truly be said to be fair, and indeed I have heard of lapses of judgement in other committees that I would attribute to fatigue (although what I have witnessed, a supreme effort on the part of my committee colleagues and the SSHRC officer assigned us, would suggest otherwise). The pressure exerted upon committee members, in terms of the four-day framework and the impact of their decisions, is tremendous, and requires perhaps inordinate amounts of both preparation and stamina. I am given to understand that SSHRC often has difficulties recruiting participants on adjudication committees, and having undergone two years of participation I can understand why.

The adjudication process should become a process spread around the calendar. There should be an initial adjudication carried out by email on an annual quarterly if not continuous basis. In this initial adjudication, high- and low-ranked files should be separated from the middle ranks, and either funded or refused (and returned to the applicant for improvement). The remaining, middle-ranked files should be set to one side, to become the subject of the annual meetings carried out at a less pressured pace.

2. Secondly there is the problem of disciplinary tensions, alluded to above. While SSHRC officers make every effort in recruiting both external readers and committee participants whose backgrounds show a track record of impartiality and professional reserve, no one truly leaves behind their predilections, their professional tastes and inclinations. Nowhere is this more apparent than in the friction between the so called "new musicology" and its presumed "old" counterpart. How is a committee to decide, let us say, between a scholar at work upon a highly specialized medieval topic and a research team devoted to understanding human musical cognition, or between a scholar working on attribution through watermarks and a scholar devoted to the sociology of recent popular music?

In selecting external readers and committee participants, SSHRC should be encouraged to enlist the services of the appropriate societies-such as CUMS/SMUC-in particular those who participate in FedCan's operations. At the very least, societies like CUMS/SMUC should have an officer who can work with SSHRC to assemble a list of potential readers (and we should all be willing to read SSHRC applications) and adjudication 
committee members. And this process should involve a vetting by the society executive board to assure the minimization of bias.

3. As mentioned, the foreign scholars that SSHRC draws upon have little, sometimes no, understanding of the dynamics of Canadian humanities and social sciences research. SSHRC is turning more and more to foreign scholars for evaluation, and this aim is laudable - to put Canadian scholarship on the world stage. But the world stage is not a level playing field; scholarship doesn't work in Lethbridge like it does in L.A. Our American colleagues in particular sometimes look upon the priorities expressed in SRG applications with bemusement (sometimes outright amusement), since they can often draw upon a graduate student population and a research infrastructure of libraries and private grants that is largely denied most Canadian researchers.

When using foreign scholars, SSHRC again should draw upon the recommendations of the Canadian societies, as suggested above. It should also explain something of the Canadian scholarly landscape-the difference between the large universities located in the big cities and the small universities in often remote locations, which are treated as largely alike by the application form. SSHRC really needs two kinds of external reader evaluations (and two different evaluation forms) - one for Canadian readers and one for foreign readers-wherein the different expertises are distinguished. The foreign evaluation could concentrate on the application from the perspective of scholarship throughout the world; the Canadian could concentrate upon the application in a native perspective.

4. On the first page of the application, the fourth box from the top, you will come across the following curious passage: "Proposal fits within the research area(s) in management, business, and finance? Yes/no." I am under no illusions that my work on Marxist theories of music production in Europe between the two world wars merits an affirmative response here. Instead, this must surely be a symptom of the political pressures SSHRC, as an agency of the federal government, submits to from time to time. (And these pressures are anything but Marxist, it goes almost without saying.)

Elsewhere in the application form itself and in the guide for the adjudication committees, we find similar symptoms. The guide describes the programmes funded by the SRG's as follows:

Council defines a program of research as a sustained research enterprise that includes one or more projects or other components, and which is shaped by broad objectives for the advancement of knowledge (emphasis mine).

And among the criteria for funding, it lists "suitability and expected effectiveness of plans to communicate research results both within and, as appropriate, beyond the academic community (emphasis mine)."

SSHRC imposes here perhaps the most severe task faced by the adjudication committee: how to decide what the broad objectives of the applicant's research are, and how these will play to those beyond the walls of academia-the taxpayer and the voter, to put it simply. Many of my colleagues still lament the disappearance of the small, sustaining SSHRC grant, say maximum $\$ 30,000$ over 
three years, enough to get overseas every summer, buy a computer, and hire a grad student to sort papers. Small grants like that don't play well to the average taxpayer (the neighbours who ask you every May 1 $1^{\text {st }}$, "So you're off for the summer, right?"). Those grants rarely had really broad objectives; they were enough to keep one going, to produce two or three articles a year, and to charge up the batteries with a European sojourn. And yet applications like them regularly reappear in adjudications, and are still funded. Many an applicant believes those aims are still ethical for a federal granting institution, despite indications by SSHRC to the contrary. What's a committee to do?

SSHRC needs the courage to tackle this issue head on. I believe it cannot go back to the small sustaining grant, certainly for logistical reasons, but more so because it is suicide in our present day federal political climate. (And it is really the responsibility of the universities and colleges to administer these grants, not an impossible task were they to devote even just one to two percent of their annual budgets to scholarly research, as the President of Athabasca University suggested at a recent meeting of FedCan.) It needs to focus the SRG's on research with well-defined and above all clearly articulated broad aims, aims defensible to the non-academic public. And it needs to tell the academic community clearly that this is its mandate (and demand of the universities that they fulfill their research mandates fully) and require its adjudication committees to observe it more closely.

I will close with an anecdote. In the1990's I became involved as a co-researcher with a multi-disciplinary SSHRC funded research project involving human kinetics and music. The project was a comparison of the techniques of expert performance preparation of hockey coaches and symphony orchestra conductors, and I worked closely with two researchers involved with sports, both of whom had good grant track records. Of all my SSHRC funded research, this project elicited the most interest-both scholarly and on the part of the layperson.

The week that SSHRC funding for the project was announced, however, a national foundation devoted to what it calls "taxpayers rights" gave a press conference at which the head of the foundation lambasted it (and other SSHRC-funded projects like it) as a waste of taxpayer's money. (When asked by a cameraman if he'd actually read the thing, he replied with a snarl that he didn't need to, since one could see from the title what a waste it truly was.) Later that week, I believe a SSHRC-funded project on medieval music by a colleague at a nearby university made it into the debate on the floor of the House of Commons.

In those two instances, we were losers at SSHRC. This is not to suggest that either project didn't merit the funding. What I would suggest in closing is that without a strong commitment to SSHRC and the SRG's on the part of the academic community, a commitment sufficient to take on SSHRC's critics, we are all losers. How to win at SSHRC? That's simple. Just give it your constant support. Defend it loudly, criticize it constructively, use it. 